\title{
Anthrovision
}

Vaneasa Online Journal

$5.1 \mid 2017$

Varia 5.1

\section{Software as Co-Teacher}

How Korsakow Disrupted an Ethnographic Film Program

Torsten Näser and Franziska Weidle

\section{(2) OpenEdition \\ Journals}

Electronic version

URL: http://journals.openedition.org/anthrovision/2507

DOI: 10.4000/anthrovision.2507

ISSN: 2198-6754

Publisher

VANEASA - Visual Anthropology Network of European Association of Social Anthropologists

\section{Electronic reference}

Torsten Näser and Franziska Weidle, « Software as Co-Teacher », Anthrovision [Online], 5.1 | 2017,

Online since 30 June 2017, connection on 01 May 2019. URL : http://journals.openedition.org/

anthrovision/2507; DOI : 10.4000/anthrovision.2507

This text was automatically generated on 1 May 2019.

(c) Anthrovision 


\section{Software as Co-Teacher}

How Korsakow Disrupted an Ethnographic Film Program

\section{Torsten Näser and Franziska Weidle}

We would like to thank our colleague Frauke Paech, who co-taught the project with us as well as the students of CVA 2015-17 for their trust and continuous involvement even after the project's official completion.

\section{Introduction (Franziska Weidle)}

1 It is the first session of the academic year. The students have gathered around the big table in our conference room. The aim of this session, we announce, is to become acquainted with the Korsakow software from a viewer's perspective. Their task is to engage with Florian Thalhofer's Planet Galata (Turkey 2010), ${ }^{1}$ an interactive online documentary authored in Korsakow, and critically reflect on their viewing experience based on a given set of questions. After some initial confusion and voiced opposition, the screens begin to flicker and the room becomes silent. About 30 minutes later, we switch the lights back on and start collecting the students' reactions and evaluations on the whiteboard. The left-hand side of the mind map quickly fills up with negative aspects color-coded in blue. Stress, boredom, distraction, repetition and small-format are among the problems they identify. Above all, the main irritation appears to stem from the lack of structure, navigation and literacy. "Where does this film end?" and "Is this a film at all?" are questions that keep coming up during the ensuing discussion. It is only after providing further context on recent academic scholarship in the field of interactive documentary as well as reminding them of our discipline's long debate on the issue of representation that the students gradually shift their attitudes towards what they have seen. 
Translated graphic depicting the students' mind map of their initial encounter with a work authored in Korsakow, 17 May 2016.

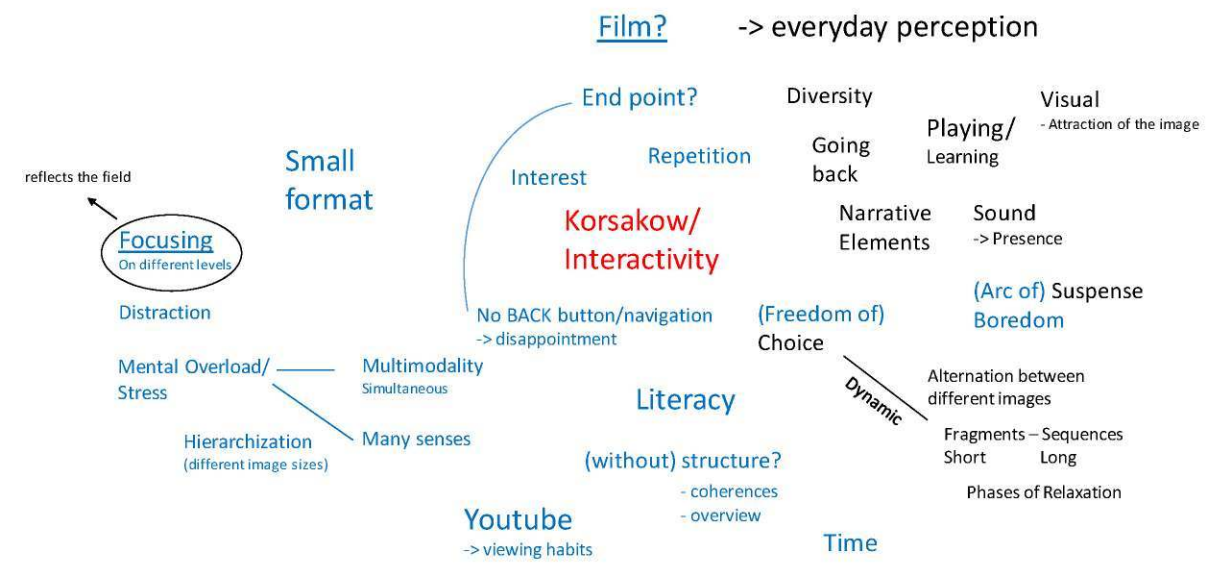

Graphic by Franziska Weidle.

2 Documentary video formats published on the internet are often subject to a direct comparison with their cinematic counterparts, implying a hierarchical relationship between the two. In fact, new forms of expression are configured by previous technologies and their accompanying production and viewing conventions just as much as they facilitate different possibilities. In the contemporary discourse on interactive documentary (i-docs), scholars and practitioners of the field primarily highlight the potential of interactivity as distinguishing affordance ${ }^{2}$ of digital media "to reconfigure the relationship between media producer, subject and audience at the heart of documentary", as recently suggested by Mandy Rose (2017:7). On the same note, Sandra Gaudenzi and Judith Aston previously remarked that "interactivity is seen as means through which the viewer is positioned within the artefact itself, demanding him, or her, to play an active role in the negotiation of the 'reality' being conveyed through the i-doc" (2012:126).

3 Whether it is an interactive user interface, hypertextuality or algorithmic processing, producing documentary content in and with computational logics puts filmmakers in an odd position. They might find it liberating to mix the languages of documentary and computational media and divert from the pressures of cinematic conventions such as narrative or expository coherence. At the same time, however, this also requires them to depart from their sometimes implicit documentary schooling, including successive production phases and the notion of a single-authored, fixed outcome. In her analysis of current i-doc productions, Gaudenzi, for instance, pointed to the methodological tensions of merging design and storytelling workflows, which "go[es] beyond the practical adoption of new processes touching upon core beliefs of individual responsibilities and power structures" within multidisciplinary teams (2017:118).

4 Accommodating diverse perspectives and negotiating reality collaboratively as part of its representation is not just at the heart of i-docs but also resonates with some of the key points frequently discussed in cultural, social and visual anthropology. While the linearity of film and the types of montage it permits are doubtlessly helpful tools to 
structure complex encounters with socio-cultural phenomena, they are foreign constructs imposed on epistemic practices, which are characterized by a complex interplay of proximity and distance, the simultaneous experience of participation and observation (cf. Hess and Schwertl 2013:15). During the master course Curriculum Visual Anthropology (CVA) of 2015-17 at the Department of Cultural Anthropology/European Ethnology in Göttingen, together with our colleague Frauke Paech we conceived our research project as an experiment to test the suitability of more open media practices for bridging the gap between fieldwork experience and interpretation. Thus, we integrated Korsakow - a "media software" (Manovich 2013:38) for authoring generative multilinear ${ }^{3}$ audio-/visual works - into our ethnographic research project Bilder machen (making images) (2017). ${ }^{4}$

\section{Project homepage}

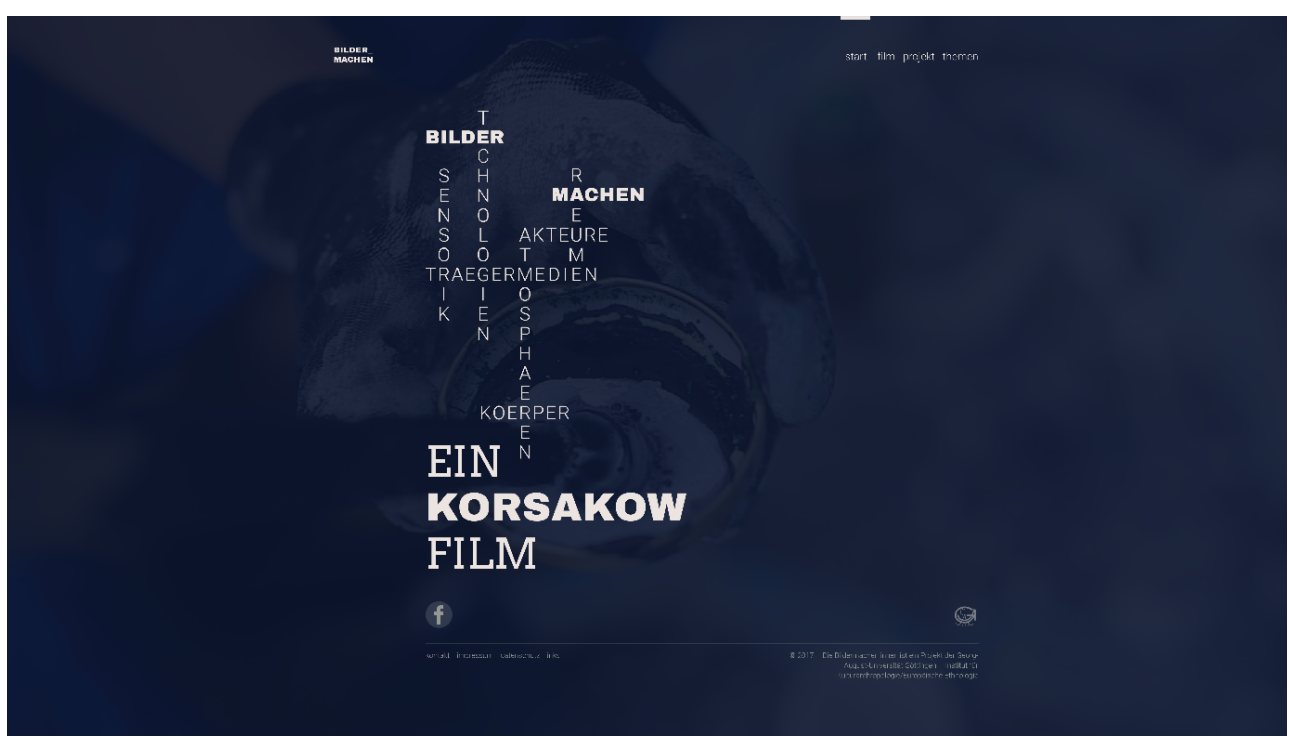

CVA 2015-17, Dept. of Cultural Anthropology/European Ethnology, University of Goettingen.

5 As exemplified by the classroom situation described at the beginning of this paper, mixing the language of documentary films with that of computational media is, hence, often challenging not only to makers but also to viewers of such works (cf. Gantier and Labour 2017:101). Multimedia online productions "transform how users engage with materials" (Coover 2011:617): they require heightened attention, a different skill set and a new form of engagement with which documentary audiences might struggle. We can also observe a curious tension stemming from documentary and, in this context, ethnographic films' ambiguous position among the conventions and demands of mainstream media culture on the one hand, and the long-term in-depth anthropological research that lies behind their often low-budgeted production, on the other. In this context, Roderick Coover critically remarks that

6 " [...] non-fiction visual research projects often take a lot of time and attention to make, and they often take plenty of time and attention to view as well. Many cannot be viewed in a single sitting, while others may require a combination of viewing, reading and/or other intellectual activity. As media converge, it therefore may be necessary to establish conditions by which once differing media are framed for reception and engagement" (2012:212). 
7 While resistance, frustration and disappointment were at the forefront of our students' initial reception experience, finding an appropriate framework for reception and engagement was only one of the challenges we faced as teachers and students of Korsakow over the course of our project. Based on unsystematic fieldwork, this paper critically reflects on the lessons learned from bringing together established and emerging media technologies in the context of an ethnographic film program. Central questions include: which conflicts emerged in the process and what does the careful examination of this specific sociotechnical constellation tell us about the standards, values and ideologies underpinning representation strategies in ethnography? In relation to current debates on interactive documentary, practice theory and (audio-)visual research methods, this contribution explores the ongoing requirement of responding to the development of new technologies and the resulting redefinition of appropriate media forms such as ethnographic film. In the space between contemporary theoretical perspectives on ethnographic filmmaking and the specific hopes held by students that motivated them to choose this career path, we can observe considerable discrepancies. By supplementing often deductive and positing discourses with a position that is sensitive to situated media production and its cultural embedding, we seek to emphasize further the significance of such inconsistencies.

8 Searching for a suitable written format, we opted for an approach that might interrupt the conventional flow and style of academic texts in favor of representing the fragmented and polyvocal genesis of this project and paper. Thus, we will switch between our individual voices as teachers of CVA and complement this experiential dimension with discursive reflections from a more distanced point of view on ethnographic filmmaking as academics in the field. With this approach, we hope to excavate gradually the implicit conventions and habitus inscribed in this institutionalized media training and offer a methodology for how to engage productively with socio-material disruptions as epistemological points of friction.

\section{CVA and Its Institutional Memory (Torsten Näser)}

9 "This is a particularly challenging moment to work with images", begins visual anthropologist Paolo Favero in one of his recent publications, and demonstrates how the multimodal, material and relational character of digital images can "become constitutive of new relations, engagements and knowledge" in the context of image-based ethnographic work (2017:275-276). Similarly, the more than thirty-year-old master program at the Department of Cultural Anthropology/European Ethnology in Göttingen mirrors shifting notions of image-making practices and their discursive and material entanglements. Moreover, the topic of image-making was also at the heart of the Korsakow project to be discussed in this paper, which is why we will dedicate the following paragraphs to a reflection upon CVA's institutional memory as context and catalyst for the conception of this project and the challenges we encountered with Korsakow.

Co-initiated by Edmund Ballhaus, one of the most prominent critics of the time, ${ }^{5} \mathrm{CVA}$ was founded as a counter draft to the dominant discourse surrounding images within the German-speaking visual anthropology of the mid-1980s. In response to the positivist notion of science and, following that, the restricted use of film postulated by IWF, the local Institute for Scientific Film, Ballhaus advocated for a conceptualization of film as 
analytical research outcome rather than as method for empirical data collection (1987:126). In addition, he saw films as independent scholarly endeavors that emerge out of and, as Ballhaus reified several years later, after the completion of an intensive phase of fieldwork (1995:25). These notions shaped CVA's direction for years to come. Many CVA productions have combined observational methods with a shooting schedule approach and included interviews and forms of montage that depart from the naturalistic gesture of direct or observational cinema. Most of them have followed the ethos of the selfresponsible anthropologist (cf. Rouch 2003, Ballhaus 1995) who autonomously conceptualizes, shoots, edits and supports the public screening of his or her film in a cinema-like setting.

11 Nowadays, the study program consists of a three-semester project dedicated to the theory and practice of ethnographic filmmaking. Students attending the program are also invited to do audiovisual work as an integral part of their master thesis. Participation in CVA is free of charge and addresses students who are interested in gaining basic methodological experiences in audiovisual anthropology. ${ }^{6}$ Without a doubt, CVA has changed since Ballhaus' retirement in 2009. The strict demarcation between fieldwork and shooting has been transformed into a case dependent integrative methodology. The primacy of narrative monographic films conceptualized for the big screen has also been mitigated for the benefits of working with video more diversely. ${ }^{7}$ A discourse space rather than a "school", CVA still functions as a "field of possibilities" (Foucault 2005:256). Against a mixed background of implicit knowledge and the aim of responding to dynamic and diversified international discourses, it still stands for a particular filmic and representational tradition within visual anthropology and its history is a significant part of its institutional memory, today.

12 For some time now, it has become common practice to determine a specific topic for each CVA project. Following the iconic turn (cf. Bachmann-Medick 2006:329-330) and contemporary perspectives on visual media (cf. Favero 2017), CVA 2015-17 was dedicated to the investigation of image creation processes in their broadened and increasingly diversifying ontologies and epistemologies. The purpose of this open approach was to tease out the different cultural and historical stratifications (cf. Bruhn 2009:12) as well as the resulting ambiguities inherent in the concept. Our aim was to combine equally established understandings of imagery as they are in connection with analog photography for instance, and digital forms, which often lack physical attachment to the empirical world (Belting 2001:38; 39) and "ask us to approach them beyond representation and indexicality" (Favero 2017:276). The CVA project from 2015 to 2017, however, preset not only the topic of image-making but also a specific perspective. According to contemporary approaches in visual studies (cf. Prinz and Reckwitz 2012), image productions are located within "complex, contextual, connotative entanglements and couplings of media, material and processes of production and mediation" (Leimgruber et al. 2013:253) (translated by T.N.). In line with anthropologist Cristina Grasseni and her concept of "skilled visions" (2010; 2011), we assumed that visions and the ways they take shape are influenced by situated processes of learning and training, which are embedded in multisensory practices (Grasseni 2010:4).

Understood as situated practices following specific and local rules of validity, the students formed groups of three to gather video material on different methods of imagemaking. In line with this overarching topic and perspective, they found protagonists that fitted the project's conception well: a blind painter, solar system researchers producing 
graphics of the sun, an enamel artist or a fully automated apparatus for biometric photos. Rather than producing stand-alone ethnographic films, however, we asked them to experiment with an alternative audiovisual format that would incorporate hundreds of short video clips within one platform to mark coherences and differences among the various field sites. It was precisely this point when Korsakow entered the scene.

\section{The Materiality of CVA 2015-17 - Introducing Korsakow (Franziska Weidle)}

14 Although there is a considerable amount of research that examines technology as "means to social, psychological, or pedagogic ends", Estrid Sørensen identifies a blind spot in these often still human-centered studies of education towards the "diverse other ways in which materials take part in social interaction" (2009:6). From the perspective of ActorNetwork-Theory (ANT), ${ }^{8}$ materiality plays a central role in social processes such as the production of knowledge (cf. Latour and Woolgar 1986; Knorr Cetina 1999). Transferring this way of thinking to the educational research field, Sørensen regards learning "as a result of a symmetric interplay of humans and materials" (2009:5) and advocates for a "minimal methodology, which does not a priori define the role of technology in practice" (2009:28). On the contrary, this approach asks us to consider how learning materials participate in an unfolding situation, and what is achieved through this particular sociomaterial constellation in the process. In the same vein, ANT teaches us to study technology and its heterogeneous components in their continual and often conflicting states of becoming (cf. Law 2004; Venturini 2010).

In the case of our student project,, the Korsakow System came to disrupt and was disrupted by its introduction into the educational environment of CVA. As "relatively flexible system" (Sørensen 2009: 86) however, Korsakow defies simple definition. In some circumstances, it is a computer program for authoring interactive documentaries, commonly known as K-films. However, the works produced with Korsakow are anything but fixed and stable. Every $\mathrm{K}$-film is unique from another but also in itself changes from one play-through to the next. Embedded in a web-based environment, every click repeatedly rearranges the given set of video shots and sequences, so-called "SNUs" (Smallest Narrative Units). Moreover, K-films differ notably in the various ways and contexts in which they have been conceived. Gradually diverging from what its inventor Florian Thalhofer originally had in mind, different practitioners have adopted different strategies to approach Korsakow's constantly redeveloping affordances and constraints. Thus, offering an account of a default usage or stereotypical viewing experience would be unfruitful here. As described elsewhere (Weidle 2016), there are multiple perspectives on this rather "fluid technology" (de Laet and Mol 2000:225) and we can only learn to understand what it is by studying what it does within a situated practice.

Following Korsakow and its participation in the context of CVA, a number of factors had to fall into place before the object could become associated with this learning environment. After turning Korsakow into the primary object of my doctorate in 2014, the conceptualization of CVA 2015-17 was deeply affected by my research interests and the fieldwork conducted at the non/fictionLab, a research center located in the Media and Communications Department at RMIT University in Melbourne. Six months of participant observation, interviews and camera-ethnography had led to the realization 
that "keywords are the heart of what makes relations amongst the clips in Korsakow" (Miles, Korsakow Workshop, 16 December 2015) and their design demands distinct workflows. In a recursive back and forth of gathering material (often captured with the built-in camera of smartphones) and importing it into the application, my research participants would start by assigning simple keywords to their clips. When exporting projects into web-ready HTML-packages, Korsakow's generative algorithm performs search inquiries based on these keywords. Each click organizes the otherwise disparate SNUs into different combinations, a process Seth Keen described as "connecting granules of video together into a web of relations" (2014:26). Watching the clips as they formed complex, multiple and variable assemblages on screen, then, would reveal rhythms and patterns that prompted further filming and gradually refined my participants' keyword designs. ${ }^{9}$

Thus, what came to matter about Korsakow in the context of CVA was pre-configured by this context just as much as it was shaped by the study program's structure and conceptualization outlined above. When planning the project, Torsten and I were particularly interested in questions around knowledge representation in cultural and social anthropology. Following John Law's notion of heterogeneous engineering (1989), ${ }^{10}$ this interest formed one of the central connecting points between Korsakow's technological features and our social activities. In line with the primary demands for more self-reflexive, polyphonic and evocative modes of representation, Korsakow's "simultaneous multiplicity" (Miles 2014:209) appeared to offer an alternative to linear continuity and narrative coherence as default organizing principles of audiovisual media. We hoped that the interplay between the author as rule-maker, the algorithmic processing of the program and the viewers as interactors ${ }^{11}$ would allow for a multilinear arrangement of footage that could retain traces of its complicated origins. Furthermore, we believed Korsakow to be a suitable tool for our praxeographical approach on imagemaking in that it could accommodate large quantities of empirical data and, similar to computer-based qualitative data analysis, would enable us to code our material and find correspondences, themes and motifs among the disparate media assets. Finally yet importantly, as an off-the-shelf and low-cost authoring tool it made interactive media production easily accessible to ethnographic filmmakers who might lack sufficient webdesign and programming skills.

Proceeding from this three-fold constellation of discursive, empirical and pragmatic concerns, many adjustments were necessary to turn Korsakow into a useful tool for our project. Most importantly, it involved the willingness to divert from these initial assumptions about Korsakow and its role. Besides rather foreseeable disconcertments, however, we did not anticipate that Korsakow would turn into a co-teacher for making, teaching and viewing ethnographic film. In the following paragraphs, we will trace the mutual co-constitution of Korsakow and our CVA project as it emerged in and through symmetrical interrelations of human, non-human, social and technical elements.

\section{Conflicts (Torsten Näser) and Strategies (Franziska Weidle) Between Tradition and Innovation}

19 From our students' initial reactions described in the beginning of this paper, a long and intense process of negotiation and modification was required before we could agree on a research design that promised to be fruitful. Not only Korsakow but the pre-determined framework of research perspective and topic had created constraints and inconsistencies 
from the outset of the project. In a back and forth movement similar to the workflow inspired by Korsakow, we will review central points of disruption throughout the course of the project that resulted in a modified filmmaking and teaching practice. While Torsten Näser will outline conflicts that arose from introducing Korsakow to the particular socio-material constellation of CVA (displayed in normal type), Franziska Weidle will discuss the respective coping strategy deployed (displayed in italics).

\section{Becoming Flexible}

The structure of the 3-semester-CVA program traditionally follows an idealized filming process to familiarize beginners with the steps needed to produce a film. By teaching basic concepts of ethnographic filmmaking such as the conventions of film language or the continuity system ${ }^{12}$ at the beginning of the course, we draw on a linear understanding of film without necessarily rendering it explicit. In this way, study programs and specifically those that have a long history and are taught regularly, reach a status of apparent naturalization even if continuously re-adjusted. As repeated speech acts, they have become embedded in discursive constellations of power (cf. Bublitz 2003:60-61). Ingrained in the organization of the program, their normalizations are reproduced in lectures, teaching materials, technical equipment and publications and, hence, cannot be deconstructed easily.

Ballhaus' paper on film and fieldwork (1995) has been especially influential for CVA's institutional memory. In this contribution, he critically examines the specificities of the fieldwork situation in relation to making a film and advocates for the completion of the research process before beginning to shoot (1995:25). Over the years, this postulation has given way to a case-by-case approach, which also led to a gradual interweaving of the previously separated field phases (cf. Eckardt and Näser 2014:280, 286). Nevertheless, the framework for making a film in the context of CVA is still a consecutive one, which Korsakow urged us to rethink.

During one of his Korsakow workshops at the non/fictionLab in 2015, new media scholar Adrian Miles pointed out common mistakes people would make when using the software. As a generative system, he cautioned the participants not to confuse it with a tool for building searchable databases characterized by navigational, branching tree structures. If you map out what the machine is going to do, he argued, there is no point in using the machine. In our filmed interview as well as in his teaching he emphasized the importance of developing the structure of a particular work with and through the respective tools:

This media file cannot be displayed. Please refer to the online document http:// journals.openedition.org/anthrovision/2507

\section{VIDEO LINK: HTTPS://VIMEO.COM/KORSAKOWRESEARCH/СOMMONMISTAKES}

As a generative system, the structure of a K-film co-emerges through the algorithmic processing of the tool. Accordingly, we encouraged our students to move from a linear process of filmmaking towards a recursive one. This implied dissolving the clear demarcation between different production stages (fieldwork, shooting and editing) even further and advocating for an early introduction of the camera in the field. Through repeatedly importing, indexing and exporting rushes, we hoped students would use Korsakow's keyword (or rule-) based procedurality for 
analyzing footage, generating new research questions and, thus, prompting further camera-led research. greater range of possibilities for working with audiovisual media. While it was our goal to realize a collective large-scale Korsakow project, we kept its structure open and, in addition, offered students the chance to use the same material for making short film portraits that could accompany the online platform. On a temporary basis, this prospect appeared to cater for the students' ambition to author a linear narrative film suitable for festival submission in order to gain symbolic capital and establish themselves in the field. In practice, however, the workload and intensity of the Korsakow project quickly pushed this option into the background for most of them.

\section{A Question of Perspective}

CVA has traditionally favored linguistic and semiotic approaches, which is why not only the cultural phenomena under study but also the films about them are typically seen as texts (cf. Ballhaus 1995:17, 25, 26). Here, Clifford Geertz's concept of thick description as contextual interpretation of social events and processes (1973:14-15) has become a key reference point for focusing on cultural expressions (cf. Näser 2014:124-125) and their mediations as "writing" (Herzfeld 2001: 25). Films that follow this cultural theory are understood as results of "processes of constructing meaning" (Ballhaus 2013:234-235; translated by T.N.). "As an academic product", Ballhaus remarked, films "should explore a topic according to aspects selected in advance [...], in order to reveal the sense and function of actions and events as well as their underlying values and social meanings" (2013:261; translated by T.N.). In response to the IWF and its preferences on material culture, focusing on human beings became one of the central claims, which, since then, has been reiterated empathically (cf. Ballhaus 2013:238) as constitutive for the films produced in the framework of CVA.

Inspired by ANT, the praxeological perspective adopted for our Korsakow project on the contrary, makes no significant difference between human beings and other material actors in a network and thus treats the interconnection of discursive and material components symmetrically (Knecht 2013:97). By placing emphasis on modes of observation and description (Knecht 2013:98), the praxeological approach, furthermore, "is clearly opposed to situating sociality and culture within the 'inner life' of the collective soul and its interpretation as a pure 'system of representation"' (Reckwitz 2003:288, translated by T.N.). Outlined in this way, the expectations held by students regarding the, at least implicitly, prefigured mode of practice with film ran contrary to 
the conception of the project. The anticipated change in perspective could only be accomplished rather slowly. This became evident, for instance, in written elaborations where some of our students utilized biographical or psychoanalytical argumentation to refer repeatedly back to analytical concepts that go directly against the praxeological approach.

In order to reduce reservations regarding the project approach we decided to render it explicit within teaching units and their didactical conception. Rather than dedicating the collective viewing and discussion of footage, for instance, to one group at a time as is the usual practice in CVA, we reconceived these meetings as laboratory sessions where all of our students were asked to show short clips that responded to a specific assignment. In highly focused sessions as the one depicted in the photograph below, students could demonstrate their growing expertise for their individual fields whilst pursuing a collective aim by comparatively discussing the fragmentary video material in its praxeological dimensions. Following methods such as the principle of trial and error, which are typical for laboratory-like atmospheres, we analyzed the video material in connection with pre-established categories and were, thus, able to strengthen, differentiate, transform, generate or dismiss them in the process. In addition, we discussed our filming approaches with regard to the question whether or not they were corresponding to these categories.

Visual lab session

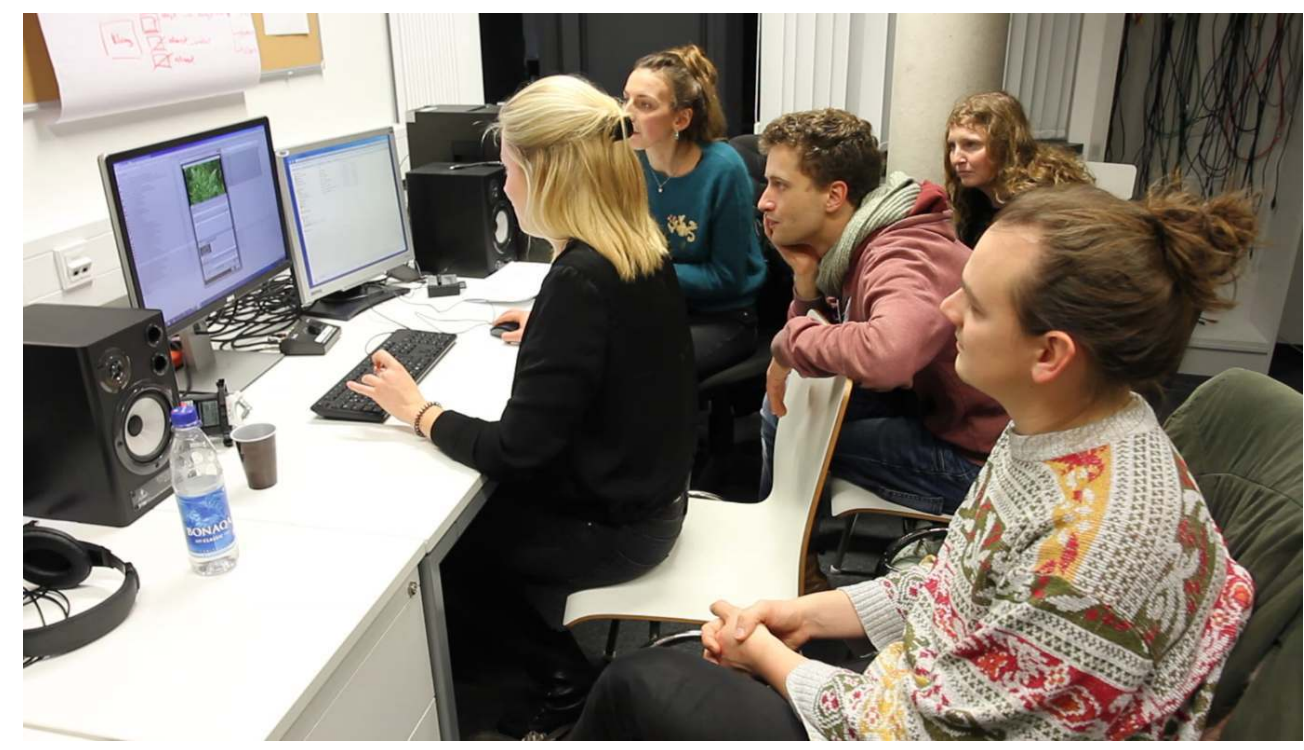

Photo by Rüdiger Brandis

As a methodology common in the area of software industry and collaborative experience design (cf. Gaudenzi 2017:120; Linington 2017:137), lab models encourage an iterative project approach from the start, which helped us to further facilitate the recursive workflow inspired by Korsakow. In the context of ethnographic fieldwork, visual anthropologist Elisabeth Mohn also emphasized that the potentials of such visual labs would lie in the ascription of new meaning to video material: "A precondition of such an approach is to subordinate the material to the respective analytical strategy rather than stylizing it as an untouchable document of situation" (2002:185, translated by F.W.]. It was exactly this shift in focus, which was grounded in our praxeological approach that advanced from an initial source of conflict to a productive space for the experimentation with different media and modes of knowledge-making within a laboratory-like atmosphere. 


\section{Organizing Randomness}

31 CVA's understanding of ethnographic film has, for a long time, referred to the individuality of the filmmaker and his or her crucial role within this interpretative approach. By classifying his cultural analysis as "an elaborate venture" (1973:6), Geertz also configured and supported the widely referenced notion of (audio visual) ethnographers as actors capable of coping with this task. ${ }^{13}$ The conception of our project was opposed to this accentuation of the filmmaker's individuality. When pursuing a praxeological approach (Knecht 2013:99), researchers and the reflexivity of their involvement in the field play a minor role. Moreover, it is also Korsakow and its affordances, which suggests shifting the focus away from the filmmaker and his or her authorial control.

One of the discrepancies between ethnographic film and web-based media production our students struggled with the most is the tension between open and fixed structures. In Rhetoric and Representation in Nonfiction Film Carl Plantinga drew attention to the fact that "no film can avoid formal structure all together" (1997:145). In contrast to expository or narrative structures, however, "open structures" would be "more episodic, meandering, and idiosyncratic than their formal counterparts" (1997:145). Since it does not need to adhere to specific requirements of conventions, Plantinga argues, an "[o]pen structure may be motivated in various ways, by the filmmaker's associations while filming, by an anthropological experiment or a journey, or by pure chance" (1997:146). As a system facilitating multilinear media arrangements, Korsakow offered an alternative approach to editing footage into a causal storyline with a beginning, middle and end. At the same time, however, its invitation to openness also presented us with a major challenge. How could we free ourselves from a coherent ordering of events and still fulfill our role as interpretative researchers?

While the reasons for the resistance displayed by our students remained ambiguous at first, the significance of the filmmaker was revealed when initiating a roundtable discussion where some students had to play the role of Korsakow advocates and others that of critics. Central to the arguments of the latter group was the question of authorial responsibility, which would be undermined by Korsakow's open- or "randomness". Since the clips imported into the system are primarily characterized by briefness and fragmentation they can hardly be thought of as individual works. Combined in a shared pool of footage, these SNUs have no credits - a feature that normally indicates authorship (cf. Bruns 2012). Moreover, the aleatory associations enabled by Korsakow's generative algorithm collided with the habitual field of the autonomous anthropologist cultivated in the CVA environment. By "posing a threat to the construction of epistemological authority in the voice of the [filming] ethnographer" (Favero 2017:285), the students struggled to surrender control in favor of facilitating multiple interpretations.

An accessible approach often utilized by Thalhofer and Miles for visualizing basic structures and developing keyword designs in Korsakow is the concept of clouds. 


\section{basic structure}

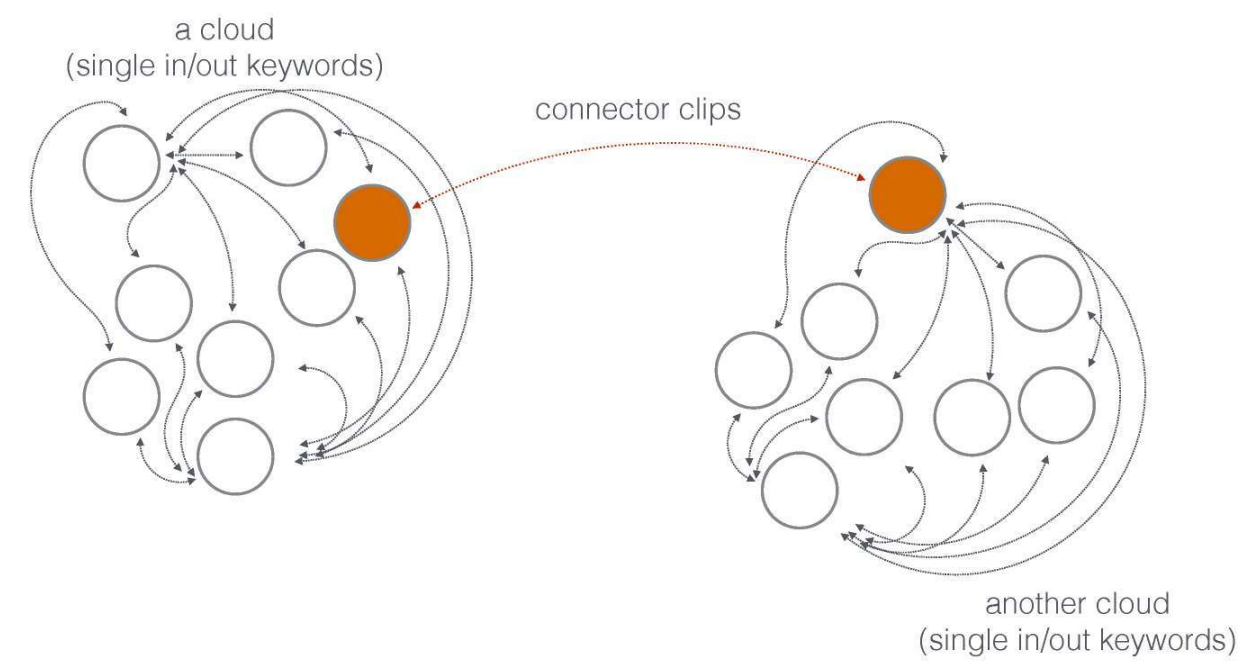

Adrian Miles, Korsakow Workshop, 16 December 2015.

A cloud is a cluster consisting of different videos and/or images that share the same IN- and OUTkeywords. In accordance with the logic of procedural rulemaking or "indexing", i.e. "using the storage capacity of computers to classify video for access and retrieval" (Keen 2014:16), keywords direct the algorithmic search. Following the "Korsakow Manual", IN-keywords "can be thought of as 'I am...' statements" and OUT-keywords as "I am looking for...' statements" (2015). ${ }^{14}$ Consequently, when editing clips in Korsakow's SNU Editor, we assigned IN-keywords to specify the respective video content and OUT-keywords to define possible relations to other clips. As the graphic above indicates, at least one clip is required to have a different OUT-keyword that matches the IN-keyword of clips forming another cloud and, thus, functioning as "connector clip" to bridge the different clusters.

Thinking in clouds made Korsakow more manageable because it offered a middle ground between absolute randomness on the one hand and linear sequentiality on the other. Based on a common repertoire of terminologies and concepts derived from the preceding literature review, we began organizing our clips in a classificatory way. ${ }^{15}$ Starting from the more general dimensions of imagemaking practices, we deductively devised a list of categories ranging from image technology and carrier to atmospheres, bodies and skilled visions. We now shared an analytical grid for observing, filming and comparing different image-making practices. By merging these categories with the notion of keywording, we developed an online keyword log that was accessible to everyone during fieldwork. We encouraged students to examine a minimum of three categories that they deemed most significant. Since the keyword log also featured a category that focused on "subjects", special emphasis could be placed on humans as image creators if necessary. Based on our students' observations, the keyword log gradually developed further and ultimately facilitated a greater interweaving of inductive and deductive approaches, which also responded to the need of attending to the particularities of each field site more flexibly. 

still unfolded agency over the course of filming by inspiring us to think through keywords, i.e. local concepts, as reference points for comparing different image-making practices with one another. Thus, in taking a comparative perspective, the log reintroduced an interpretative moment, which we then translated into a cloud-based structure for the collectively authored Korsakow project.

Building clouds by translating categories into keywords

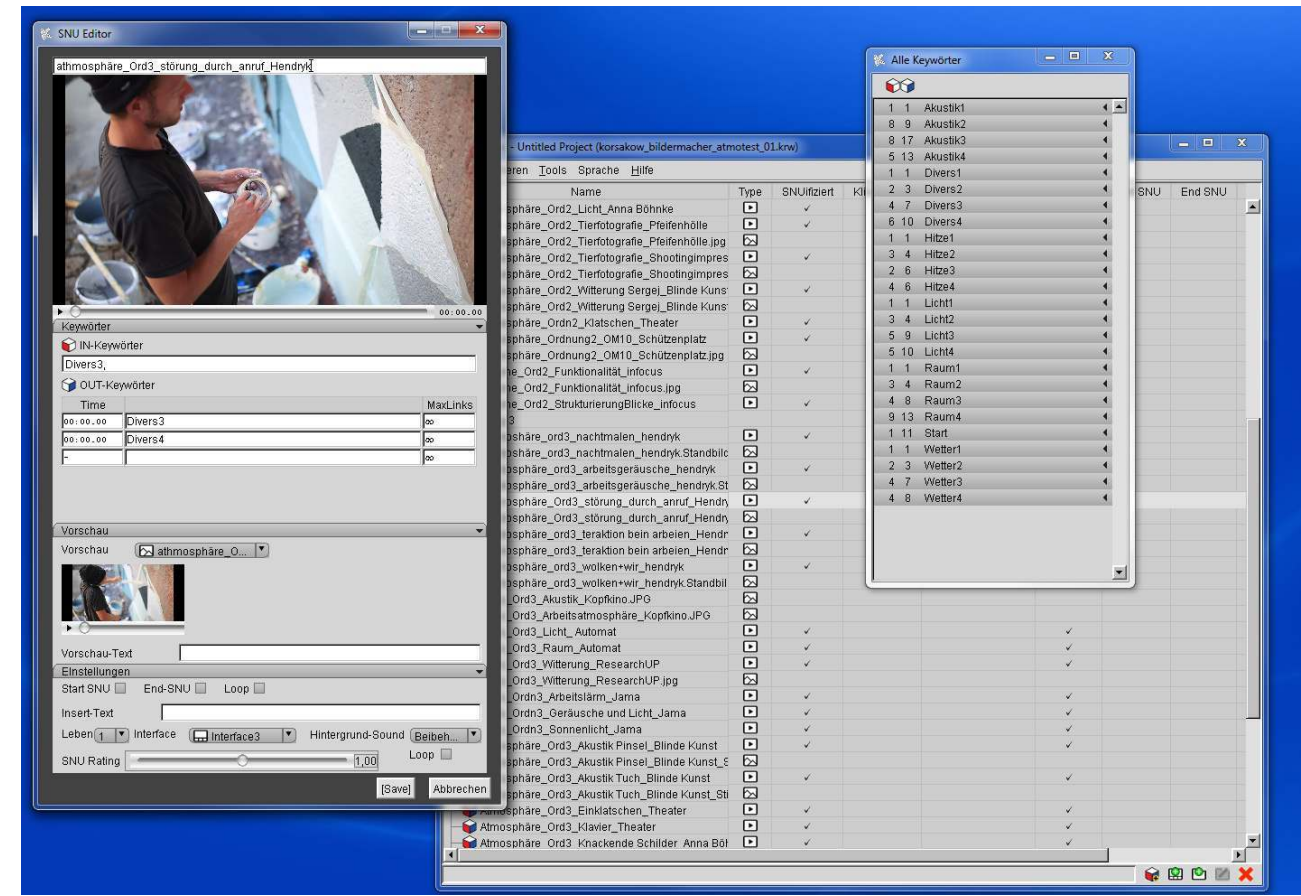

Screenshot by Franziska Weidle.

While clouds themselves would follow a linear logic, a recurring home page was introduced to ensure an open and thematically driven entry point. Drawing on Bordwell and Thompson's categorical and associational non-narrative form (2010), our process of classification allowed us to act in a structured way. At the same time, this very structure was still open enough for Korsakow's algorithm to unfold its agency over the arrangement of clouds and sub-clouds. In visual lab sessions during which we collectively viewed SNUs and test-clouds for certain categories, new cross-comparisons, juxtapositions and unexpected relations emerged that continuously drew our attention to the many similarities and differences between the image-making practices.

Our creative activity is not only a combination of theory and practice but also a synthesis of cinematic conventions and computational affordances. Coping with the tensions stemming from these, to some extent dialectically opposed, modes of knowledge-making resulted in a permanent balancing act. While thinking in clouds offered us a way to create categorical or rule-based coherence, which we combined with other Korsakow-specific affordances such as sound and interface design, the clips that became SNUs in the system were shot with professional camera equipment and had to be prepared outside of Korsakow with established video editing software. Via these clips, cinematic conventions re-entered our project.

Since the behaviour of SNUs was supposed to mirror our praxeological perspective, we encouraged close-ups and static, mainly single-shot, short clips as the main editing strategy. Interlinked in 
thematic sub-clouds, these would facilitate direct comparisons between practices while provoking curiosity by raising more questions than providing answers. However, in line with our interpretative role as ethnographers, we also agreed on other SNU formats: utilizing narrative coherence, longer sequences and trailers would contextualize the shorter clips and offer interpretations. These different organizing devices cross-fertilized each other. At the same time, they also presented a didactic strategy to respond to the students' needs of acquiring basic filmmaking skills and rendering individual authorships more transparent. Nevertheless, they also generated new challenges such as the necessary standardization of different SNU types and the focus on a set of keywords for which enough students needed to produce content to create a useful basis of comparison.

\section{Becoming an Ethnographic Curator}

41 Although CVA has been experimenting for some time with alternative screening venues for its productions (cf. Näser 2013), the cinema is still the traditional choice for presenting films to an interested public. At the same time, this convention nurtures expectations of students attending courses in ethnographic filmmaking. As a place of imagination, the cinema is also closely tied to other implicit understandings such as screenings at festivals, which together form part of the dissemination arena of ethnographic films. In this constellation, the habitus of the documentary field as it has been outlined by Jacob Gross (2013) is realized paradigmatically. With their „individual handwritings" and "intellectual discourses" (Gross 2013:405, translated by T.N.), documentaries serve as objectified cultural capital, which can be accumulated at festivals (Gross 2013:402-405). Here, filmmakers play a significant role as authors of their works. Especially in the context of Q\&A sessions, which are obligatory at many festivals, they can enact the conventionalized self-concept as educator and critic of the dominant political system (Gross 2013:403).

CVA 2015-17 contradicted this field logic. Instead of linear documentary films with an individual handwriting, we asked our students to produce SNUs - short clips allowing no authorial reference. Instead of working on formats closely associated with film festivals, the students were confronted with Korsakow and its presentation on computer, tablet or smartphone screens. The frictions discussed in this paper must be seen in light of these different formats of knowledge as well as their varying social embedding. Due to our aim of taking a new perspective on ethnographic filmmaking, it is possible that students interpreted our approach as an affront to a format's identity, which led them to Göttingen in the first place. Similar to their own initial reception experience described at the beginning of this paper, questions of dissemination and user engagement re-occurred frequently throughout the course of our project. To what extent could we frame our Korsakow work in a way that it could still be understood as an authorial and meaningful ethnographic film?

Strategies regarding a framework for reception and engagement involved the design of an appropriate website as well as the planned presentation of the project in the context of an interactive live event.. The latter responds to our students' aspiration for appearing as filmmakers in a cinema-like screening of the project. Designing plays a significant role when making webbased documentaries (cf. O'Flynn 2012:156; Keen 2014:33). Due to their unfixed nature and embeddedness in computational and hybrid "media ecologies" (Horst et al. 2010), Keen advocates for "the development of a different set of skills and knowledge compared to linear editing for 
television broadcast" (2014:76). Exploring the possibilities of "spatial montage" (Manovich 2001) as a way of utilizing the distinct affordances of computer screens and their Graphic User Interfaces is only one of many aspects that requires further investigation. ${ }^{16}$ Besides experimenting with different interface designs such as the ones for facilitating cross-comparisons and others for narration (see illustrations below), other methods included prototyping and beta testing to improve gradually the structural, narrative and graphic design of our project.

Interface for short SNUs

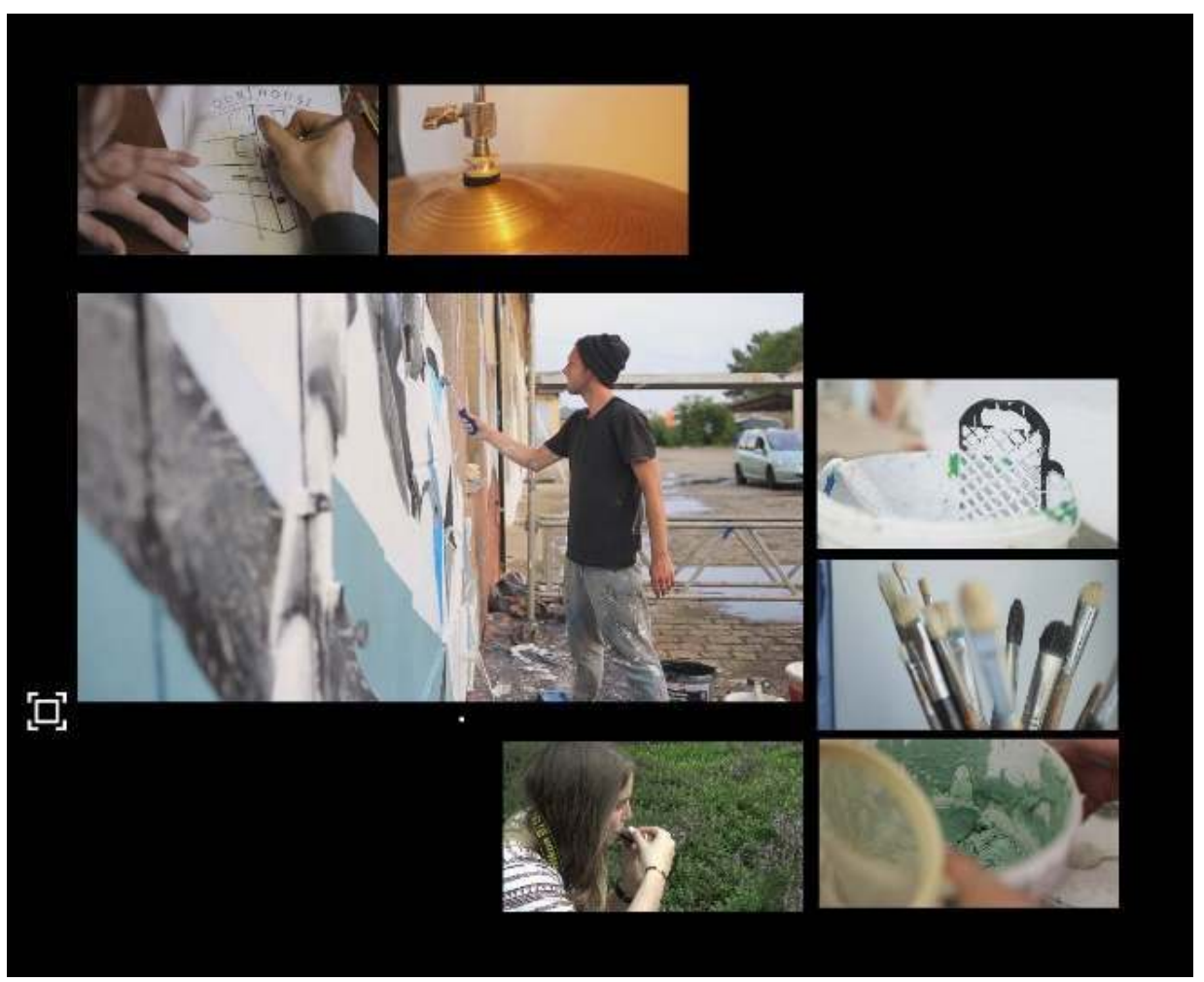

CVA 2015-17, Dept. of Cultural Anthropology/European Ethnology, University of Goettingen. 


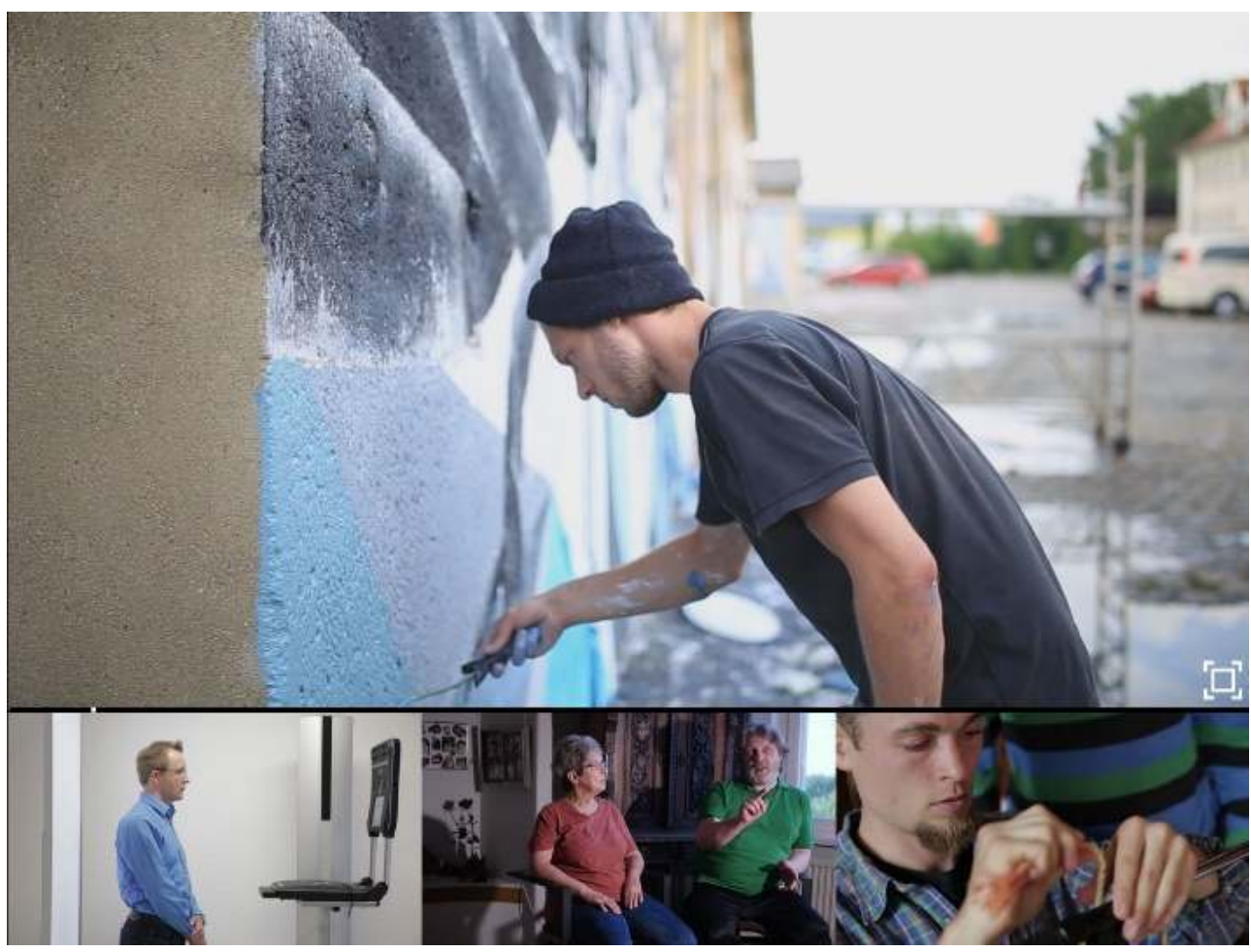

CVA 2015-17, Dept. of Cultural Anthropology/European Ethnology, University of Goettingen

In the process of collaborating with potential interactors and their experience of our project, we broadened our understanding of filmmakers and viewers of digital ethnographic media. Following Kate Nash, the potential of a "categorical webdoc" does not so much lie in "the temporal ordering of elements" but rather in "the comparisons and associations the user is invited to make between the documentary's elements" (2012:205). Facilitating such invitations and making them appealing and accessible to the interactors required us to work beyond the means of film language. In line with Favero's recent observation, we had to become ethnographic curators:

"In today's digital landscapes, where multimodality and the incorporation of the viewing and co-authoring strategies of the spectators generate a set of innovative relations [...], the role, intentions and authoriality of the ethnographer assume new meaning. No longer directors or authors, ethnographers must start viewing themselves as curators of ethnographic content" (2017:284).

Through engaging with Korsakow and its affordances, questions of user experience design empowered the students in a novel way but also confronted them with a different set of requirements and responsibilities. While exploring the possibilities of classification and navigation, it was never certain whether or not interactors would and should become aware of the cloud-based logics behind the interface and, thus, the author's' choices.

\section{Concluding Remarks (Torsten Näser and Franziska Weidle)}

Implicit forms of usage and milieu-specific standards evolve around every media format. Ethnographic film is no exception (see Crawford 1993, Näser 2014). As we move into educational institutions, such norms become clearly visible. In the case of teaching 
ethnographic filmmaking in an academic context, the respective media (or knowledge) format is likely to be reduced to the "common sense" of that particular social milieu. While students are frequently confronted with standardized methods and episteme, outside of university at film festivals, conferences or in publications experienced representatives of the discipline advocate for project-based and flexible usages of the format. One reason for placing special emphasis on the identity of ethnographic film might be seen in the ongoing need for justifying its existence. In terms of modularized courses which, generally, follow a rigid time plan, are fixed in study regulations and formulated in curricula, it appears rather likely that specific hegemonic and, thus, sedimented understanding of filmmaking in anthropology are continuously reproduced.

These fixations occur in every institutionalized training course (see Berger and Luckmann 1997:56-57), no matter which school of thought, trend or paradigm they follow. Whether intentional or not, changing the socio-technological constellation within a particular institutionalization can function as a disruptive "breaching experiment" (Garfinkel 2008) that reveals such underlying notions and related standardizations. In the case of CVA, which is historically oriented towards linear narrative films, our softwarebased approach to multilinear online documentary led to the depicted exposure of skilled practice. The master program's conceptualization but also its socio-material reproduction was brought to the surface.

Korsakow and its affordances as well as the research perspective it suggested created the necessary requirements to repeatedly put up for negotiation the way ethnographic film is regularly taught in Göttingen. Since the project outlined in this paper initially proceeded according to the standard routine, situations of conflict at first appeared as more or less usual disruptions of seminars. Gradually recognizing and reflecting these situations as epistemological points of friction, however, enabled us to develop project-oriented solutions and take a meta-perspective on ethnographic film as medium of dissemination with specific formatting practices. Moreover, Korsakow encouraged us to scrutinize aspects of filmmaking that are rarely addressed in depth in methodological discussions such as social expectations associated with the media format ranging from specific practices and styles, to the autonomous filmmaker as dominant role model or specific contexts of presentation including film festivals that promise an appropriate display of oeuvre and author.

Based on these experiences, we recommend subjecting routinized processes of institutionalized film programs to disruptions. We regard it an important aspect of teaching to interrogate habitual procedures. This includes exposing curricula to influences that go beyond the usual methodological and epistemological adjustments but rather stimulate fundamental uncertainties in the production of knowledge. In our opinion, it is imperative to address these questions for an ongoing dialogue, "a central element of a reciprocal process which challenges existing norms, institutionalized practices and forms of knowledge" (Berkin and Kaltmeier 2012:13, translated by F.W.). Since dialogues require different positions, it is necessary to recreate continuously such experiences of difference.

In the context of (audio-)visual methodologies in anthropological research, our experiment with Korsakow has demonstrated the value of digital and web specific affordances within the intricate processes of interpreting and translating cultural experience. From narrative to rule-based coherence, clearly every topic requires a specific presentation format, which, again, produces different kinds of knowledge. As an 
analytical tool in the context of a praxeographical approach, Korsakow's generative algorithm has proved to be a fruitful way of organizing empirical data and creating different pathways through the material. By retaining this multilinear arrangement, the software also made it possible to involve an interested public in open-ended associative evocations and multiple interpretations of the same content. The primary challenge was to develop a methodology that integrated different modes of expression in a way that we could live up to our role as interpretative researchers without undermining the algorithm's agency. While online environments are always hybrid ones, ethnographers will need to advance their skills into different directions in order to tap the full potential of coexisting media forms and modes of representation.

\section{BIBLIOGRAPHY}

\section{Books and articles}

Aarseth, Espen. 1997. Cybertext: Perspectives on Ergodic Literature. Baltimore, Maryland: Johns Hopkins University Press.

Aston, Judith. 2010. Spatial Montage and Multimedia Ethnography: Using Computers to Visualize Aspects of Migration and Social Division Among a Displaced Community. Forum Qualitative Social Research 11(2), art. 36. http://nbn-resolving.de/urn:nbn:de:0114-fqs1002361 (accessed 15 March 2017).

Aston, Judith and Sandra Gaudenzi. 2012. Interactive Documentary. Setting the Field. Studies in Documentary Film 6(2):125-139.

Bachmann-Medick, Doris. 2006. Cultural Turns. Neuorientierungen in den Kulturwissenschaften. Reinbek: Rowohlt.

Ballhaus, Edmund. 1987. Der volkskundliche Film. Ein Beitrag zur Theorie- und Methodendiskussion. Hessische Blätter für Volkskunde 21:108-130.

Ballhaus, Edmund. 1995. Film und Feldforschung. Überlegungen zur Frage der Authentizität im kulturwissenschaftlichen Film. In (eds) Edmund Ballhaus and Beate Engelbrecht, Der Ethnographische Film. Eine Einführung in Methoden und Praxis, pp.13-46. Berlin: Reimer.

Ballhaus, Edmund. 2013. Kulturwissenschaftliche Erkenntnis als dokumentarische Inszenierung. Dokumentarfilm aus Göttingen. In (ed.) Edmund Ballhaus, Dokumentarfilm. Schulen - Projekte Konzepte, pp.234-264. Berlin: Reimer.

Belting, Hans. 2001. Bild-Anthropologie. Entwürfe für eine Bildwissenschaft. München: W. Fink.

Berger, Peter and Thomas Luckmann. 1997. Zur gesellschaftlichen Konstruktion der Wirklichkeit. Eine Theorie der Wissenssoziologie. Frankfurt/Main: Suhrkamp.

Berkin, Sarah Corona and Olaf Kaltmeier. 2012. Im Dialog: Methodologische Überlegungen zu Horizontalität und Reziprozität in den Sozial- und Kulturwissenschaften. In (eds) Olaf Kaltmeier and Sarah Corona Berkin, Methoden dekolonialisieren. Eine Werkzeugkiste zur Demokratisierung der Sozial- und Kulturwissenschaften, pp.7-16. Münster: Westfälisches Dampfboot. 
Brasier, Hannah. 2017. A Networked Voice: Speculative Transformations of Essayistic Subjectivity in Online Environments. Studies in Documentary Film 11(1):28-44.

Bruhn, Matthias. 2009. Das Bild. Theorie, Geschichte, Praxis. Berlin: Akad.-Verl.

Bruns, Katja. 2012. Credits. Filmlexikon. http://filmlexikon.uni-kiel.de/index.php?

action=lexikon\&tag=det\&id=7265 (accessed 31 January 2017).

Bublitz, Hannelore. 2003. Diskurs. Bielefeld: Transcript.

Callon, Michel and John Law. 1997. After the Individual in Society: Lessons on Collectivity from Science, Technology and Society. Canadian Journal of Sociology 22:165-182.

Coover, Roderick. 2011. Interactive Media Representation. In (eds) Eric Margolis and Luc Pauwels, The SAGE Handbook of Visual Research Methods, pp. 617-637. Los Angeles and London: Sage.

Coover, Roderick. 2012. Visual Research and the New Documentary. Studies in Documentary Film 6 (2): 203-215.

Crawford, Peter Ian. 1993. Film as Discourse: The Invention of Anthropological Realities. In (eds) Peter Ian Crawford and David Turton, Film as Ethnography, pp. 66-82. Manchester: Manchester University Press.

De Laet, Marianne and Annemarie Mol. 2000. The Zimbabwe Bush Pump: Mechanics of a Fluid Technology. Social Studies of Science 30(2):225-263.

Eckardt, Sandra and Torsten Näser. 2014. Ethnografisch Filmen. In (eds) Christine Bischoff, Karoline Oehme-Jüngling and Walter Leimgruber, Methoden der Kulturanthropologie, pp.273-290. Bern: Haupt.

Elsaesser, Thomas und Malte Hagener. 2007. Filmtheorie zur Einführung. Hamburg: Junius.

Favero, Paolo. 2017. Curating and Exhibiting Ethnographic Evidence: Reflections on Teaching and Displaying with the Help of Emerging Technologies. In (eds) Larissa Hjorth, Heather Horst, Anne Galloway and Genevieve Bell, The Routledge Companion to Digital Ethnography, pp.275-287. New York: Routledge.

Foucault, Michel. 2005. Analytik der Macht. Frankfurt and Main: Suhrkamp.

Gantier, Samuel and Michel Labour. 2017. Evaluating Users' Experiences. A Case Study Approach to Improving i-doc UX Design. In (eds) Judith Aston, Sandra Gaudenzi and Mandy Rose, $i$-docs. The Evolving Practices of Interactive Documentary, pp.101-116. New York: Columbia University Press.

Garfinkel, Harold. 2008. Seeing Sociologically. The Routine Grounds of Social Action. Boulder: Paradigm Publications.

Gaudenzi, Sandra. 2017. User Experience versus Author Experience. Lessons Learned from the UX Series. In (eds) Judith Aston, Sandra Gaudenzi and Mandy Rose, $i$-docs. The Evolving Practices of Interactive Documentary, pp.117-128. New York: Columbia University Press.

Geertz, Clifford. 1973. The Interpretation of Cultures: Selected Essays. New York: Basic Books.

Gifreu-Castells, Arnau. 2011. Basic Characteristics of the Interactive Documentary. i-docs. http:// i-docs.org/2011/12/25/basic-characteristics-of-the-interactive-documentary-featuring-theinteractive-documentary-ii/ (accessed 1 September 2017).

Grasseni, Cristina. 2011. Skilled Visions. Toward an Ecology of Visual Inscriptions. In (eds) Marcus Banks and Jay Ruby, Made to be Seen. Perspectives on the History of Visual Anthropology, pp.19-44. Chicago: University of Chicago Press. 
Grasseni, Cristina, ed. [2007] 2010. Skilled Visions: Between Apprenticeship and Standards. New York, Oxford: Berghahn Book.

Gross, Jakob. 2013. Der Habitus des dokumentarischen Feldes. In (ed.) Edmund Ballhaus, Dokumentarfilm. Schulen - Projekte - Konzepte, pp.398-412. Berlin: Reimer.

Herzfeld, Michael. 2001. Anthropology. Theoretical Practice in Culture and Society. Malden, Oxford, Carlton: Blackwell.

Hess, Sabine and Maria Schwertl. 2013. Vom Feld zur „Assemblage“? Perspektiven europäischethnologischer Methodenentwicklung - eine Hinleitung. In (eds) Sabine Hess, Johannes Moser and Maria Schwertl, Europäisch-ethnologisches Forschen. Neue Methoden und Konzepte, pp.13-38. Berlin: Reimer.

Horst, Heather, Becky Herr-Stephenson and Laura Robinson. 2010. Media Ecologies. In (eds) Mizuko Ito, Sonja Baumer, Dan Perkel et al, Hanging Out, Messing Around and Geeking Out: Kids Living and Learning with New Media, pp.29-78. Cambridge, MA: MIT Press.

Husmann, Rolf. 1983. Film and Fieldwork: Some Problems Reconsidered. In (eds) Nico C. R Bogaart and Henk W. E. R. Ketelaar, Methodology in Anthropological filmmaking. Papers of the IUAESIntercongress, Amsterdam 1981, pp.93-111. Göttingen: F.R.G: Herodot.

Keen, Seth. 2014. Netvideo, Nonvideo, Newvideo: Designing a Multilinear Nonnarrative Form for Interactive Documentary. An exegesis submitted in partial fulfilment of the requirements for the degree of Doctor of Philosophy. RMIT University: http://www.sethkeen.net/phd/sethkeenPhD.pdf (accessed 3 March 2017).

Knecht, Michi. 2013. Nach Writing Culture, mit Actor-Network: Ethnografie/Praxeografie in der Wissenschafts-, Medizin- und Technikforschung. In (eds) Sabine Hess, Johannes Moser and Maria Schwertl, eds.Europäisch-ethnologisches Forschen. Neue Methoden und Konzepte, pp.79-106. Berlin: Reimer.

Knorr Cetina, Karin. 1999. Epistemic Cultures: How the Sciences Make Knowledge. Cambridge, MA: Harvard University Press.

Landow, George P. 1992. Hypertext: The Convergence of Contemporary Literary Theory and Technology. Baltimore: Johns Hopkins University Press.

Latour, Bruno. 1999. Pandora's Hope - Essays on the Reality of Science Studies. Cambridge, MA: Harvard University Press.

Latour, Bruno and Steve Woolgar 1986. Laboratory Life: The Construction of Scientific Facts. Princeton, NJ: Princeton University Press.

Law, John. 1989. Technology and Heterogeneous Engineering: The Case of Portuguese Expansion. In (eds) Wiebe E. Bijker, Thomas P. Hughes and Trevor Pinch, The Social Construction of Technological Systems: New Directions in the Sociology and History of Technology, pp.111-134. Cambridge, MA: MIT Press.

Law, John. 2004. After Method. Mess in Social Science Research. Oxon: Routledge.

Leimgruber, Walter, Silke Andris and Christine Bischoff. 2013. Visuelle Anthropologie: Bilder machen, analysieren, deuten und präsentieren. In (eds) Sabine Hess, Johannes Moser and Maria Schwertl, Europäisch-ethnologisches Forschen. Neue Methoden und Konzepte, pp.247-281. Berlin: Reimer.

MacDougall, David. 2006. The Corporeal Image. Film, Ethnography, and the Senses. Princeton, NJ: Princeton University Press. 
Manovich, Lev. 2001. The Language of New Media. Cambridge, MA: MIT Press.

Manovich, Lev. 2013. Software Takes Command. Bloomsbury. Open Access: https://

www.bloomsburycollections.com/book/software-takes-command/ (accessed 3 March 2017).

Miles, Adrian. 2014. Materialism and Interactive Documentary: Sketch Notes. Studies in Documentary Film 8(3):205-220.

Miles, Adrian. 2017. Matters of Concern and Interactive Documentary: Notes for a Computational Nonfiction. Studies in Documentary Film 0(0):1-17.

Mohn, Elisabeth. 2002. Filming Culture. Spielarten des Dokumentierens nach der Repräsentationskrise. Stuttgart: Lucius \& Lucius.

Mol, Annemarie. 2010. Actor-Network Theory: Sensitive Terms and Enduring Tensions. Kölner Zeitschrift für Soziologie und Sozialpsychologie 50(1):253-269.

Murray, Janet. 2012. Inventing the Medium: Principles of Interaction Design as a Cultural Practice. Cambridge: MIT Press.

Nash, Kate. 2012. Modes of Interactivity: Analysing a Webdoc. Media, Culture and Society 34(2):195210.

Näser, Torsten. 2013. Dezentrale Perspektiven. Skizzen zu Film, (Kunst-)Raum und mehrspurigem Erzählen. In (ed.) Edmund Ballhaus, Dokumentarfilm. Schulen - Projekte - Konzepte, pp.312-324. Berlin: Reimer.

Näser, Torsten. 2014. Film und Text. Ethnografische Wissensformate im Diskursvergleich. Berlin: Lit. Näser, Torsten. 2015. Movements-of-Migration.org - Ein Archiv als Vermittlungsinstanz. In (eds) Sabine Hess and Torsten Näser, Movements of Migration. Neue Positionen im Feld von Stadt, Migration und Repräsentation, pp.98-112. Berlin: Panama.

Norman, Donald. 2013 [1998]. The Design of Everyday Things. New York: Basic Books.

O’Flynn, Siobhan. 2012. Documentary's Metamorphic Form: Webdoc, Interactive, Transmedia, Participatory and Beyond. Studies in Documentary Film 6(2):141-157.

Prinz, Sophia and Reckwitz, Andreas. 2012. Visual Studies. In (ed.) Stephan Moebius, Kultur. Von den Cultural Studies bis zu den Visual Studies, pp.176-195. Bielefeld: Transcript

Reckwitz, Andreas. 2003. Grundelemente einer Theorie sozialer Praktiken. Eine sozialtheoretische Perspektive. Zeitschrift für Soziologie. 32(4):282-301.

Rose, Mandy. 2017. Co-Creation Preface. In (eds) Judith Aston, Sandra Gaudenzi and Mandy Rose, $i$-docs. The Evolving Practices of Interactive Documentary, pp.7-8. New York: Columbia University Press.

Rouch, Jean. 2003. The Camera and Man. In (ed.) Paul Hockings, Principles of Visual Anthropology, pp.79-98. Berlin: Mouton de Gruyter.

Ruby, Jay. 2000. Picturing Culture. Explorations of Film and Anthropology. Chicago: University of Chicago Press.

Schlumpf, Hans-Ulrich. 1987. Warum mich das Graspfeilspiel der Eipo langweilt. Gedanken zur Wissenschaftlichkeit ethnologischer Filme. In (ed.) Rolf Husmann, Mit der Kamera in fremden Kulturen. Aspekte des Films in Ethnologie und Volkskunde, pp.49-65. Emsdetten: Andreas Gehling. Sørensen, Estrid. 2009. The Materiality of Learning: Technology and Knowledge in Educational Practice. New York: Cambridge University Press. 
Venturini, Tommaso. 2010. Diving in Magma: How to Explore Controversies with Actor-Network Theory. Public Understanding of Science 19(3):258-273.

Walter, Florian. 2014. Kollaborative Feld- und Filmforschung. Gleichberechtugte Formen der Kommunikation und transkulturelle Verstehensprozesse. Berliner Blätter 67:56-67.

Weidle, Franziska. 2016. Korsakow Perspective(s): Rethinking Documentary Knowledge in Digital Multilinear Environments. VIEW Journal of European Television History \& Culture 5(10):110-123. http://viewjournal.eu/non-fiction-transmedia/korsakow-perspectives/

\section{Films}

Thalhofer, Florian, dir. 2010. Planet Galata. http://www.planetgalata.com/ (accessed 11 January 2017).

Walter, Florian and Maruch de la Crúz Pérez, dir. 2008. On the Road with Maruch. Göttingen. 45 min.

Websites

Planet Galata. http://www.planetgalata.com/ (accessed 27 September 2017)

Bilder Machen - Investigation on Image Creation Processes. http://bildermachen.unigoettingen.de/ (accessed 27 September 2017)

Curriculum Visuelle Anthropologie, Universität Göttingen. http://www.kaee.uni-goettingen.de/ cva/ (accessed 12 Jan. 2017)

Movements of Migration - Ein Wissensarchiv. http://www.movements-of-migration.org/cms/ (accessed 14 Jan. 2017)

\section{NOTES}

1. See http://www.planetgalata.com/ (accessed 27 September 2017).

2. Coined by Donald Norman, affordance refers to "the relationship between the properties of an object and the agent's capacity to determine how the object could possibly be used" (Norman 2013:10).

3. In contrast to film and its linear time-based sequence of images, hypertextual systems enable tempo-spatial connections that are multi- or nonlinear. In the context of hypertext theory, the term nonlinearity has been scrutinized primarily because it negates the role of linearity in hypertext (cf. Landow 1992; Aarseth 1997). Since temporal continuity is still a significant aspect of the way a work is perceived, we will adopt Seth Keen's definition of multilinearity to describe structures "made in a system that facilitates multiple relations between separate granules. The system and the audience can link these separate granules, in the form of shots and sequences, into different combinations" (Keen 2014:11).

4. See: http://bildermachen.uni-goettingen.de/ (accessed 27 September 2017).

5. Among others, Hans-Ulrich Schlumpf also took a critical position towards the Göttingen-based Institute for Scientific Film (Institut für den wissenschaftlichen Film, IWF). (1987).

6. The CVA program is complemented by several practical and theoretical courses of the Department's BA and MA curricula: see http://www.kaee.uni-goettingen.de/cva/ (accessed 12 Jan. 2017).

7. One example was the CVA project of 2011-13 during which the students screened their films not only in a cinema but also in the local art center and other public spaces as integrated part of 
an artistic exhibition; see http://www.movements-of-migration.org/cms/ (accessed 14 Jan. 2017); and Näser (2015).

8. As a central approach in empirical studies of science, technology and society (known as Science and Technology Studies), ANT rests on the principle of general symmetry, i.e. the notion that the world consists of ever shifting networks of relations between human and nonhuman, material and semiotic agencies (cf. Latour 1999:174-215; Callon and Law 1997). Rather than providing a coherent explanatory framework or perspective, this concept (or non-theory) functions as a theoretical and methodological repertoire that aims at mapping and describing these relations. As such, it has been influential in promoting a view on materiality that seeks to underline its agency, not only as an equally important participant in the constitution of scientific knowledge but in a variety of empirical fields including educational practices. For a critical retrospection on the genesis of ANT, cf. Mol 2010.

9. For further reading on the specific practice with Korsakow at the non/fictionLab cf. Miles 2017; Brasier 2017 and Weidle 2016.

10. According to Law, technology can be described as a result of continuously aligning and realigning social activities and interests with technological features until they are connected in a relatively stable way.

11. A number of terminologies refer to the recipients of i-docs. Since "user" can denote both, the software user as well as the user of the work, we call the viewers "interactors" (Gifreu-Castells 2011; Murray 2012) to differentiate the two but also to highlight the dual role of the audience as assembling and simultaneously viewing an interactive work.

12. Moreover, media scholars Thomas Elsaesser and Malte Hagener, for instance, show how the continuity system - a concept encompassing many of the conventional forms of filmic expression - correlates closely with a linear unfolding of the relations between sites and movements in film (2007:113-114).

13. Summarizing all of the texts discussing the filmmaker's person and her or his influence to the filmic process would exceed this article's capacity. Referring to the most obvious concepts such as the autonomously filming anthropologist as well as the debates on reflexivity (cf. Husmann 1983:102-103; Ballhaus 1995:14; Ruby 2000:151-152; Rouch 2003:87; MacDougall 2006:26-27) should be sufficient to illustrate the vast extent this field of argumentation has reached.

14. See: http://korsakow5.korsakow.org/learn/manual/ (accessed 15 March 2017).

15. This approach is linked closely to grounded theory and its method of theoretical coding. Due to the focus on pedagogy here, a more in depth comparison between Korsakow and software for qualitative data analysis such as atlas.ti or MAXQDA will be the topic of another paper. As an example for other ethnographic approaches to Korsakow's keywording principle, cf. Walter (2014) and his co-authored film On the Road with Maruch (2008), which he turned into an interactive multimedia installation with the help of Korsakow. For an example in the documentary context, cf. Seth Keen (2014) who utilized classification and indexing processes for structuring material in his $\mathrm{PhD}$ project.

16. For a discussion of the potential of "scrolling environments" in documentary representations, see Coover 2011. For spatial montage in the context of ethnography, see Aston 2010. 


\section{ABSTRACTS}

When new technologies are introduced to an established film program, not only students but also teachers face a series of chances and challenges. In the masters course Curriculum Visual Anthropology (CVA) of 2015-17 at Göttingen's Department of Cultural Anthropology/European Ethnology, it was the Korsakow System with its particular affordances and constraints that stirred things up significantly. The premise of this paper is to reflect critically on the coconstitution of technology and practice within the student research project's particular "materiality of learning" (Sørensen 2009). As a result of disrupting the "skilled visions" (Grasseni 2010) of ethnographic filmmaking, we argue, implicit conventions and inscribed ideologies of institutionalized trainings are brought to the surface.

Quand les nouvelles technologies sont introduites dans un programme institutionnalisé d'enseignement du film, ce sont tant les élèves que les professeurs qui doivent faire face aux nouvelles opportunités ainsi qu'aux nouveaux défis offerts par ces technologies. A l'université de Göttingen, entre 2015-2017 dans le cours de maîtrise dédié à l'anthropologie visuelle, au sein du département d'anthropologie culturelle et d'ethnologie européenne, ce fut les potentialités et les contraintes spécifiques du système Korsakow qui ont clairement fait bouger la situation. Le but de cet article vise à apporter une réflexion critique sur la co-constitution d'une technique et d'une pratique avec le projet de recherche des étudiants consacré à la "matérialité de l'apprentissage "(Sørensen 2009). Comme le résultat fut de perturber "les visions expertes" (Grasseni 2010) du film ethnographique, nous démontrons que les conventions implicites et les idéologies sous jacentes aux formations institutionnalisées se sont révélées.

Cuando se introducen nuevas tecnologías en un programa de cine ya establecido, no sólo los estudiantes sino también los profesores se enfrentan a una serie de oportunidades y retos. En el curso de master de Antropología Visual (CVA) de 2015-17 del Departamento de Antropología Cultural / Etnología Europea de Göttingen, fue el Sistema Korsakow -con sus particularidades y limitaciones- que puso estas cuestiones sobre la mesa de manera significativa. La premisa de este artículo es reflexionar críticamente sobre la co-constitución de la tecnología y la práctica dentro de la "materialidad del aprendizaje" particular del proyecto de investigación del estudiante (Sørensen 2009). Argumentamos que, con la interrupción de las "visiones entrenadas" (Grasseni 2010) del cine etnográfico las convenciones implícitas y las ideologías inscriptas de los procesos de aprendizaje institucionalizados salen a la superficie.

\section{INDEX}

Keywords: ethnographic film, digital media, teaching methodology, Korsakow

Mots-clés: film ethnographic, média numérique, méthode d'enseignement, Korsakow

Palabras claves: cine etnográfico, media digital, enseñar metodología, Korsakow 


\section{AUTHORS}

\section{TORSTEN NÄSER}

University of Goettingen, Dept. of Cultural Anthropology/European Ethnology

Dr. Torsten Näser is a postdoctoral researcher and lecturer at the Department of Cultural Anthropology/European Ethnology at the University of Goettingen in Germany, where he coordinates and teaches the CVA masters program. Furthermore, he is the spokesperson of the working group "Film and Audio Visual Anthropology" within the Deutsche Gesellschaft für Volkskunde (dgv) and member of GIEFF e.V., an association that organizes an ethnographic film festival every two years. His $\mathrm{PhD}$ project focused on the discursive differences between written and filmic ethnographic practices. His research interests and courses comprise various aspects of (ethnographic) film, photography, media anthropology and visual studies.

tnaeser1@gwdg.de

\section{FRANZISKA WEIDLE}

University of Goettingen, Dept. of Cultural Anthropology/European Ethnology Franziska Weidle is a PhD candidate at the Department of Cultural Anthropology/European Ethnology at the University of Goettingen in Germany. Furthermore, she is a research fellow at the German Research Foundation (DFG) Training Group "Literature and Dissemination of Literature in the Digital Age". Her research interests involve installation, filmmaking, photography and new media as forms of ethnographic knowledge production and dissemination. In her PhD project, she focuses on the role of software in contemporary documentary practices. From 2015 to 2016, she was a visiting research scholar at RMIT University's non/fictionLab where she co-founded the Docuverse Group (http://nonfictionlab.net.au/t/docuverse/).

fweidle@gwdg.de 